\title{
Стан заготівлі та використання тромбоцитарних компонентів крові в Україні
}

Мета - проаналізувати стан донорства, донацій клітин крові та використання тромбоцитів у клінічній практиці за останні 6 років. Об’єкт і методи дослідження. Використані дані галузевої статистичної звітної форми № 39-здоров «Звіт центру служби крові (станції переливання крові), відділення трансфузіології лікувального закладу, установи, лікарні, яка проводить заготівлю крові» областей, міста Києва та відомчих закладів за період 2014-2019 рр. Проведена статистична обробка даних. Результати. Апаратами цитаферезу на кінець 2019 р. оснащені всі заклади служби крові. Укожній області функціонують 1-4, увідділеннях трансфузіології лікувальних закладів Міністерства охорони здоров'я України - 6-9 такихапаратів. Загалом в Україні їх налічується 73. Кількість донорів клітин крові збільшилася на 85, 7\%. Кількість донацій збільшилася у 2, 4 раза. Це, у свою чергу, сприяло значному зростанню об'ємів заготовлених аферезних тромбоцитів за 6 років - у 2,7 раза. Кількість заготовлених тромбоцитів із 500 мл консервованої крові залишилась майже на такому самому рівні. На 96,9\% більше передано тромбоцитів у заклади охорони здоров'я для лікувальних цілей: у 2019 р. - 38588 доз, що майже повністю забезпечило потребу лікарень. Висновки. Широке впровадження у роботу центрів (станцій) переливання крові методу апаратного цитаферезу дозволяє забезпечити заклади охорони здоров'я концентратом тромбоцитів для лікування хворих, яким необхідний цей компонент крові.

Ключові слова: донори, донації, аферезні тромбоцити, концентрат тромбоцитів із 500 мл консервованої крові, оснащеність апаратурою.

\section{Вступ}

У клінічній практиці наявний великий попит на тромбоцити, які застосовують для лікування значної кількості хворих у різних галузях медицини, зокрема у пацієнтів із лейкемією, апластичною анемією, солідними пухлинами, пацієнтів хірургічного профілю тощо. Потреба у тромбоцитах постійно зростає. Активне впровадження в службу крові методу апаратного цитаферезу дозволяє суттєво збільшити об'єми заготівлі аферезних тромбоцитів.

У схемах лікування хворих на лейкемію, апластичну анемію, солідні пухлини, а також пацієнтів хірургічного профілю, відповідно до клінічних протоколів, необхідно застосовувати концентрат тромбоцитів. Потреба в них постійно зростає (Всемирная организация здравоохранения, 2019). Тому забезпеченість лікувальних закладів охорони здоров'я концентратами тромбоцитів залежить від планової роботи установ системи крові (Видиборець С.В., Сергієнко О.В. (ред.), 2019).

Мета - проаналізувати стан донорства, донацій клітин крові, заготівлю тромбоцитів центрами (станціями) переливання крові та їх використання у клінічній практиці за останні 6 років.

\section{Об 'єкт і методи дослідження}

Використанідані галузевої статистичної звітної форми № 39-здоров «Звіт центру служби крові (станції переливання крові), відділення трансфузіології лікувального закладу, установи, лікарні, якапроводить заготівлю крові» областей, міста Києва та відомчих закладів за період 2014-2019рр. Проведена статистична обробка даних.

\section{Результати та їх обговорення}

Оснащення закладів системи крові апаратами цитаферезу розпочалося у 2006 р., коли, відповідно до Програми розвитку донорства крові та її компонентів на 2002-2007 роки, затвердженої Постановою Кабінету Міністрів України від 26.10.2001 р. № 1403 (Кабінет Міністрів України, 2001), Міністерством охорони здоров'я (МО3) України були закуплені перші 5 апаратів (АР Крим, Запорізька (2 апарати), Київська, Тернопільська області). У подальшому їх кількість суттєво збільшувалась і на кінець 2019 р. становила 73 одиниці (табл. 1).

За останні 6 років значно збільшилась і кількість донорів клітин крові: у 2014 р. ї було 5342, а у 2019 р. - 9922, тобто на $85,7 \%$ більше (рис. 1).
Спостерігається також збільшення у 2,4 раза кількості донацій клітин крові (у 2014 р. - 6334 , у 2019 р. - 15 109) (табл. 2). Це, у свою чергу, сприяло значному зростанню об'ємів заготовлення аферезних тромбоцитів: у 2019 р. виготовлено 30618,4, а у 2014 р. - тільки 11408,5 доз. Як видно з табл. 3, кількість вироблених аферезних тромбоцитів збільшилась у 2,7 раза.

Що стосується одержання тромбоцитів із 500 мл консервованої крові, то у зв'язку з широким впровадженням у практику центрів (станцій) переливання крові апаратного цитаферезу по-

Таблиця 1. Оснащеність, апарати для цитаферезу

\begin{tabular}{|c|c|c|c|c|c|c|}
\hline \multirow{2}{*}{$\begin{array}{c}\text { Найменування регіону } \\
\text { та відомства }\end{array}$} & \multicolumn{6}{|c|}{ Рік } \\
\hline & 2014 & 2015 & 2016 & 2017 & 2018 & 2019 \\
\hline Вінницька & 1 & 1 & 1 & 1 & 1 & 2 \\
\hline Волинська & 1 & 1 & 1 & 1 & 1 & 1 \\
\hline Дніпропетровська & 3 & 3 & 3 & 4 & 4 & 4 \\
\hline Донецька & - & - & - & - & 1 & 2 \\
\hline Житомирська & 1 & 1 & 1 & 1 & 1 & - \\
\hline Закарпатська & 1 & 1 & 1 & 1 & 1 & 1 \\
\hline Запорізька & 2 & 2 & 2 & 2 & 2 & 2 \\
\hline Івано-Франківська & 1 & 1 & 1 & 1 & 1 & 2 \\
\hline Київська & 3 & 3 & 9 & 9 & 9 & 3 \\
\hline Кіровоградська & 1 & 1 & 1 & 1 & 1 & 1 \\
\hline Луганська & 1 & 1 & 1 & 1 & 1 & 1 \\
\hline Львівська & 1 & 2 & 2 & 2 & 2 & 2 \\
\hline Миколаївська & 2 & 2 & 2 & 2 & 3 & 3 \\
\hline Одеська & 3 & 3 & 3 & 3 & 3 & 4 \\
\hline Полтавська & 1 & 1 & 1 & 1 & 2 & 2 \\
\hline Рівненська & 1 & 1 & 1 & 1 & 1 & 1 \\
\hline Сумська & 1 & 1 & 1 & 1 & 1 & 1 \\
\hline Тернопільська & 1 & 1 & 1 & 2 & 2 & 2 \\
\hline Харківська & 1 & 1 & 1 & 2 & 2 & 4 \\
\hline Херсонська & - & - & 2 & 1 & 2 & 2 \\
\hline Хмельницька & 1 & 2 & 2 & 2 & 2 & 1 \\
\hline Черкаська & 1 & 1 & 3 & 3 & 3 & 3 \\
\hline Чернівецька & 1 & 1 & 1 & 1 & 1 & 1 \\
\hline Чернігівська & - & - & 1 & 1 & 1 & 1 \\
\hline м. Київ & 2 & 2 & 2 & 3 & 3 & 3 \\
\hline Загалом & 31 & 33 & 44 & 47 & 51 & 49 \\
\hline ВТЛЗ М03 України & 6 & 8 & 10 & 13 & 13 & 22 \\
\hline $\begin{array}{l}\text { Міністерство оборони } \\
\text { України }\end{array}$ & 1 & 1 & 1 & 1 & 1 & 1 \\
\hline ВТЛЗ НАМН України & 1 & 1 & 1 & 1 & 1 & 1 \\
\hline Україна & 39 & 43 & 56 & 62 & 66 & 73 \\
\hline
\end{tabular}


Таблиця 2. Кількість донацій клітин крові

\begin{tabular}{|c|c|c|c|c|c|c|}
\hline \multirow{2}{*}{$\begin{array}{c}\text { Найменування регіону } \\
\text { та відомства }\end{array}$} & \multicolumn{6}{|c|}{ Рік } \\
\hline & 2014 & 2015 & 2016 & 2017 & 2018 & 2019 \\
\hline Вінницька & 234 & 266 & 405 & 189 & 360 & 697 \\
\hline Волинська & 32 & - & - & 319 & 217 & 208 \\
\hline Дніпропетровська & 529 & 1061 & 969 & 858 & 1346 & 1127 \\
\hline Донецька & - & - & 500 & - & 69 & 221 \\
\hline Житомирська & 618 & 514 & 333 & 300 & 462 & 576 \\
\hline Закарпатська & - & 82 & 69 & 91 & 163 & 188 \\
\hline Запорізька & 743 & 702 & 684 & 230 & 353 & 634 \\
\hline Івано-Франківська & 215 & 332 & 398 & 296 & 284 & 428 \\
\hline Київська & 747 & 1757 & 920 & 404 & 404 & 824 \\
\hline Кіровоградська & 18 & 19 & 55 & 106 & 132 & 223 \\
\hline Луганська & 232 & - & 52 & 45 & 101 & 61 \\
\hline Львівська & 509 & 566 & 596 & 565 & 681 & 701 \\
\hline Миколаївська & 209 & 332 & 123 & 183 & 315 & 614 \\
\hline Одеська & 195 & 286 & 558 & 400 & 645 & 601 \\
\hline Полтавська & 343 & 377 & 412 & 354 & 502 & 257 \\
\hline Рівненська & 80 & 128 & 96 & 177 & 172 & 184 \\
\hline Сумська & 139 & 42 & 509 & 186 & 364 & 575 \\
\hline Тернопільська & 49 & 48 & 124 & 22 & 98 & 61 \\
\hline Харківська & 259 & 343 & 404 & 261 & 918 & 1173 \\
\hline Херсонська & - & - & 31 & 180 & 339 & 466 \\
\hline Хмельницька & 45 & 70 & 186 & 207 & 185 & 447 \\
\hline Черкаська & 612 & 734 & 658 & 871 & 1418 & - \\
\hline Чернівецька & 79 & 122 & 140 & 119 & 212 & 325 \\
\hline Чернігівська & - & - & 11 & 93 & 184 & 226 \\
\hline м. Київ & 261 & 118 & 792 & 1165 & 1112 & 1438 \\
\hline Загалом & 6148 & 7889 & 9025 & 7621 & 11036 & 12255 \\
\hline ВТЛЗ М03 України & - & 2260 & 1910 & 2151 & 2090 & 2594 \\
\hline $\begin{array}{l}\text { Міністерство оборони } \\
\text { України }\end{array}$ & 143 & 207 & 161 & 161 & 103 & 80 \\
\hline ВТЛЗ НАМН України & 43 & 59 & 88 & 68 & 84 & 180 \\
\hline Україна & 6334 & 10415 & 11184 & 10001 & 13313 & 15109 \\
\hline
\end{tabular}

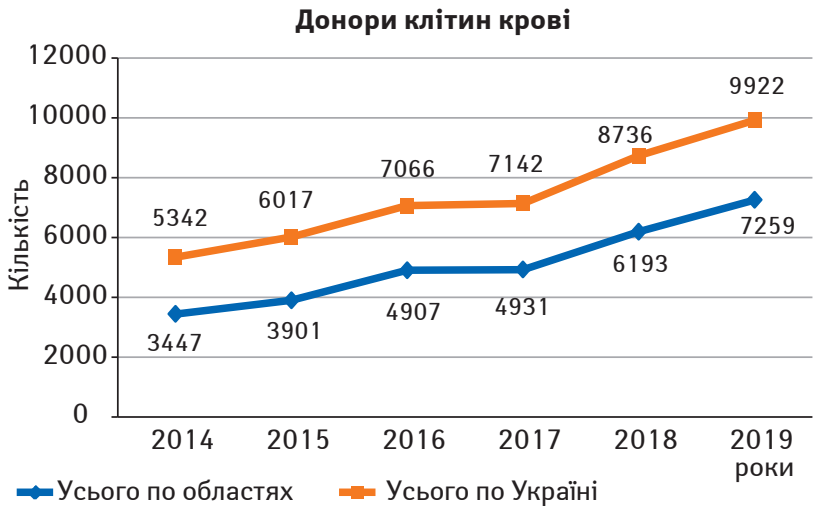

Рис. 1. Донори клітин крові

треба у виготовленні таких тромбоцитів майже відпадає, про що свідчать показники їх заготівлі. За 6 років вони майже не змінилися і становлять близько 10 тис. доз на рік (рис. 2).

Відповідно до даних про оснащеність апаратурою для цитаферезу, кількість донорів, донацій клітин крові, виготовлених тромбоцитів збільшується і кількість доз тромбоцитів, виданих

Виготовлено тромбоцитів, концентрат 3500 мл консервованої крові, доз

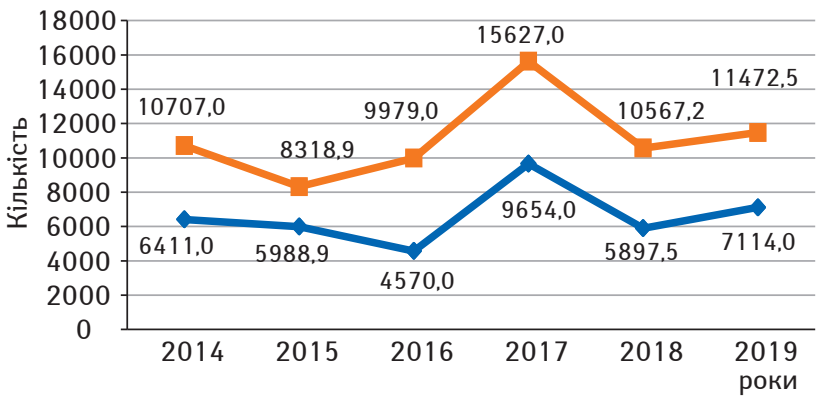

—Усього по областях $=$ Усього по Україні

Рис. 2. Виготовлено тромбоцитів, концентрат із 500 мл консервованої крові
Таблиця 3. Виготовлено аферезних тромбоцитів, доз

\begin{tabular}{|c|c|c|c|c|c|c|}
\hline \multirow{2}{*}{$\begin{array}{c}\text { Найменуван- } \\
\text { ня регіону } \\
\text { та відомства }\end{array}$} & \multicolumn{6}{|c|}{ Рік } \\
\hline & 2014 & 2015 & 2016 & 2017 & 2018 & 2019 \\
\hline Вінницька & 485,0 & 539,0 & 783,0 & 363,0 & 718,0 & 1471,0 \\
\hline Волинська & 32,0 & - & 420,0 & 630,0 & 417,0 & 530,0 \\
\hline $\begin{array}{l}\text { Дніпропетров- } \\
\text { ська }\end{array}$ & 1234,0 & 2216,0 & 1915,0 & 1692,0 & 2545,0 & 2244,0 \\
\hline Донецька & - & - & 107,8 & 189,0 & 209,0 & 414,5 \\
\hline Житомирська & 782,0 & 763,0 & 626,0 & 598,0 & 919,0 & 1148,0 \\
\hline Закарпатська & - & 221,0 & 191,0 & 318,0 & 466,0 & - \\
\hline Запорізька & 791,0 & 752,0 & 782,3 & 295,5 & 472,0 & 780,3 \\
\hline $\begin{array}{l}\text { Івано-Франків- } \\
\text { ська }\end{array}$ & 398,0 & 590,0 & 700,0 & 529,5 & 527,0 & 771,0 \\
\hline Київська & 1486,0 & 1970,0 & 1838,0 & 808,0 & 1224,0 & 1648,0 \\
\hline Кіровоградська & 31,0 & 38,0 & 110,0 & 195,5 & 250,0 & 454,0 \\
\hline Луганська & 662,0 & - & 120,5 & 112,0 & 225,0 & 159,0 \\
\hline Львівська & 1109,0 & 1081,0 & 1192,0 & 1136,0 & 1355,0 & 1415,0 \\
\hline Миколаївська & 627,0 & 2070,0 & 907,0 & 1311,0 & 1412,0 & 2149,0 \\
\hline Одеська & 391,0 & 469,0 & 556,0 & 558,0 & 1002,0 & 951,0 \\
\hline Полтавська & 661,0 & 737,0 & 789,5 & 687,0 & 963,0 & 1402,8 \\
\hline Рівненська & 123,0 & 255,5 & 190,0 & 354,0 & 343,0 & 348,0 \\
\hline Сумська & 139,0 & 128,0 & 460,0 & 197,0 & 766,0 & 1168,0 \\
\hline Тернопільська & 49,0 & 48,0 & 124,0 & 22,0 & 98,0 & 135,0 \\
\hline Харківська & 498,0 & 226,0 & 765,0 & 487,0 & 1716,0 & 2102,0 \\
\hline Херсонська & - & - & 61,0 & 350,0 & 656,0 & 906,5 \\
\hline Хмельницька & 180,0 & 85,0 & 185,0 & 327,0 & 329,5 & 580,5 \\
\hline Черкаська & 785,0 & 679,0 & 660,0 & 1058,0 & 1418,0 & - \\
\hline Чернівецька & 79,0 & 244,0 & 238,5 & 197,0 & 272,0 & 336,0 \\
\hline Чернігівська & - & - & 12,0 & 150,5 & 360,5 & 438,5 \\
\hline м. Київ & 455,0 & 224,0 & 1631,0 & 2425,0 & 2214,0 & 2831,0 \\
\hline Загалом & 10997,0 & 13335,5 & 14172,6 & 14990,0 & 20877,0 & 24383,1 \\
\hline $\begin{array}{l}\text { ВТЛЗ М03 } \\
\text { України }\end{array}$ & 193,0 & 5220,0 & 4989,0 & 5073,0 & 5789,0 & 5893,3 \\
\hline $\begin{array}{l}\text { Міністерство } \\
\text { оборони України }\end{array}$ & 143,0 & 207,0 & 161,0 & 161,0 & 103,0 & 80,0 \\
\hline $\begin{array}{l}\text { ВТЛЗ НАМН } \\
\text { України }\end{array}$ & 75,5 & 111,0 & 158,0 & 125,0 & 316,0 & 262,0 \\
\hline Україна & 1408, & 8873 , & 9480 & 0349 & 7085,0 & 30618,4 \\
\hline
\end{tabular}

у лікувально-профілактичні заклади. 3 лікувальною метою у 2014 р. використано 19 598, у 2019 р. - 38588 доз, тобто на 96,9\% більше, що майже повністю забезпечило потребу лікарень (рис. 3).

При цьому зазначимо, що списання тромбоцитів із різних причин було мінімальним і становило 1-27 доз на рік.

Як же виглядає виробництво закладами служби крові тромбоцитів у сегменті «запит - пропозиція»? На сьогодні єдиним офіційним критерієм, який визначає потребу регіонів у компонентах і препаратах крові, зокрема концентраті тромбоцитів, є Розпорядження Кабінету Міністрів України від 22.11.2017 р. № 833-р «Про затвердження обсягів обов'язкового забезпечення потреб охорони здоров'я населення донорською кров'ю, її компонентами і препаратами на 2018 рік», які визначаються щорічно за заявкою областей (Кабінет Міністрів України, 2017).

Аналіз виконання Розпорядження Кабінету Міністрів України за період 2015-2018 рр. за розділом «Концентрат тромбоцитів, доз» свідчить, що завдання щорічно виконувалися на 101-143\%. Окремі області - Закарпатська, Івано-Франківська, Одеська, Сумська, Тернопільська, Черкаська, Чернігівська - план виконали не повністю. Але є області, які план перевиконали - Дніпро-

Видано тромбоцитів лікувально-профілактичним закладам, доз

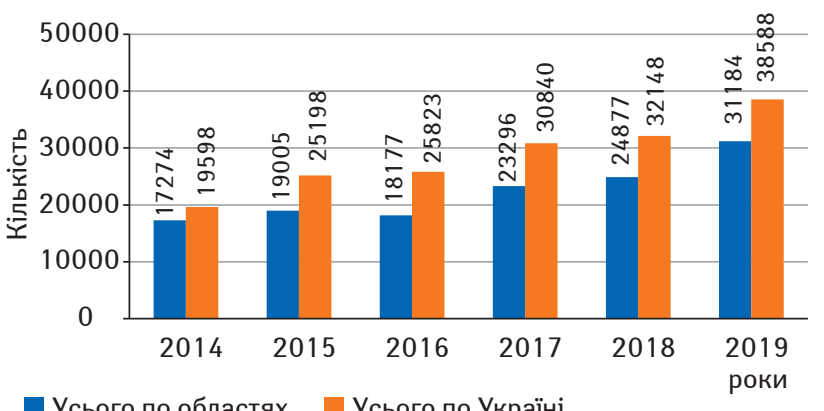

Усього по областях

Рис. 3. Видано тромбоцитів лікувально-профілактичним закладам 
петровська, Кіровоградська, Львівська, Полтавська, Херсонська, Чернівецька, місто Київ та ін.

Таким чином, перехід станцій (центрів) переливання крові на нові технології одержання концентрату тромбоцитів - апаратний цитаферез - дозволяє забезпечити потреби у тромбоцитах закладів охорони здоров'я. Це стало можливим завдяки цілеспрямованій роботі колективів закладів системи крові щодо оснащення необхідною апаратурою, ефективному залученню донорських кадрів, значному збільшенню як кількості донацій, так і заготовлених тромбоцитів.

\section{Висновок}

Широке впровадження методу апаратного цитаферезу в роботу центрів (станцій) переливання крові дозволяє забезпечити заклади охорони здоров'я концентратом тромбоцитів для лікування хворих, яким потрібен цей компонент крові.

\section{Список використаної літератури}

Видиборець С.В., Сергієнко О.В. (ред.) (2019) Організація трансфузіологічної допомоги в закладах охорони здоров'я. Київ - Вашингтон, 261 с.

Всемирная организация здравоохранения (2019) Клиническое применение крови. Памятка для национальных программ в области здравоохранения (http://www.who.int/bloodsafety/clinical use/AM CUB Russian.pdf).

Кабінет Міністрів України (2001) Постанова Кабінету Міністрів України від 26.10 .2001 р. № 1403 «Про затвердження Програми розвитку донорства крові та її компонентів на 2002-2007 роки».

Кабінет Міністрів України (2017) Розпорядження Кабінету Міністрів України від 22.11.2017 р. № 833-р «Про затвердження обсягів обов'язкового забезпечення потреб охорони здоров'я населення донорською кров'ю, її компонентами і препаратами на 2018 рік».

\section{Состояние заготовки и использования тромбоцитарных компонентов крови в Украине}

\section{П.М. Перехрестенко, Е.М. Аладьева, В.Н. Самусь}

Резюме. Цель - проанализировать состояние донорства, донаций клеток крови и использования тромбоцитов в клинической практике за последние 6 лет. Объект и методы исследования. Использованы данные отраслевой статистической отчетной формы № 39-здрав «Отчет центра службы крови (станции переливания крови), отделения трансфузиологии лечебного учреждения, учреждения, больницы, которая проводит заготовку крови» областей, города Киева и ведомственных учреждений за период 2014-2019 гг. Проведена статистическая обработка данных. Результаты. Аппаратами цитафереза на конец 2019 г. оснащены все учреждения службы крови. В каждой области функционируют 1-4, в отделениях трансфузиологии лечебных учреждений Министерства здравоохранения Украины - 6-9 таких аппаратов. Всего по Украине их насчитывается 73. Количество доноров клеток крови увеличилось на 85,7\%. Количество донаций увеличилось в 2, 4 раза. Это, в свою очередь, способствовало значи тельному росту объемов заготовленных аферезных тромбоцитов за 6 лет - в 2,7 раза. Количество заготовленных тромбоцитов из 500 мл консервированной крови осталось почти на том же уровне. На 96,9\% больше передано тромбоцитов в учреждения здравоохранения для лечебных целей: в 2019 г. - 38588 доз, почти полностью обеспечило потребность больниц. Выводы. Широкое внедрение в работу центров (станций) переливания крови метода аппаратного цитафереза позволяет обеспечить учреждения здравоохранения концентратом тромбоцитов для лечения больных, которым необходим этот компонент крови.

Ключевые слова: доноры, донации, аферезные тромбоциты, концентрат тромбоцитов из 500 мл консервированной крови, оснащенность аппаратурой.

\section{State of preparation and use of blood platelet components in Ukraine \\ P.M. Perekhrestenko, O.M. Aladieva, V.M. Samus}

Summary. Aim - to analyze the state of donation, blood cell donation and platelet use in clinical practice over the past 6 years. Object and methods of research. The data of the sectoral statistical reporting form № 39-health «The report of the Blood Service Center (Blood Transfusion Station), transfusion department of a medical institution, institutions, hospitals that collect blood" in the regions, Kyiv city and departmental institutions for 2014-2019 years were used. Statistical processing of data was carried out. Results. At the end of 2019, all blood service facilities are equipped with cytopheresis devices. There are 1-4 in each region and in transfusion departments of medical institutions of the Ministry of Health of Ukraine - 6-9 such devices. In total in Ukraine there are 73 . The number of blood cell donors has increased by $85.7 \%$. The number of donations increased 2.4 times. This, in turn, contributed to a significant 2.7-fold increase in the volume of harvested apheresis platelets over 6 years. The number of harvested platelets from $500 \mathrm{ml}$ of canned blood remained almost at the same level. $96.9 \%$ more platelets were transferred to health care facilities for medical purposes: in $2019-$ 38588 doses were almost completely met by the need for hospitals. Conclusions. The widespread introduction of blood cytopheresis by blood transfusion centers (stations) allows to provide health care facilities with platelet concentrate for the treatment of patients who need this blood component.

Key words: donors, donations, apheresis platelets, platelet concentrate of $500 \mathrm{ml}$ of canned blood, equipment.

\section{Адреса для листування:}

Перехрестенко Петро Михайлович

04060, Київ, вул. Максима Берлинського, 12

Державна установа «Інститут гематології

та трансфузіології НАМН України»,

відділ трансфузіології

E-mail: igt.org@ukr.net 